\title{
Flesh parasites of fish from central Philippine waters
}

\author{
F. Petersen ${ }^{1}$, H. Palm ${ }^{1}$, H. Möller ${ }^{1}$, M. A. Cuzi ${ }^{2}$ \\ ${ }^{1}$ Institut für Meereskunde, Düsternbrooker Weg 20, W-2300 Kiel, Germany \\ ${ }^{2}$ University of San Carlos, Marine Biology Section, Cebu City 6015, Philippines
}

\begin{abstract}
In April 1990, 488 marine fish, belonging to 30 species from central Philippine waters, were investigated macroscopically for the occurrence of parasites in their flesh and for anisakid nematodes in their body cavity. Twenty-four fish were found to be infected by 1 of 4 different types of parasites. Unidentified Microspora were found in 4 host species from different families. Plerocercoids of the trypanorhynchid cestode Otobothrium penetrans occurred in the flesh of hemirhamphids and belonids only. Adult nematodes of the genus Philometra were found in the garfish Tylosurus crocodilus. The only parasite found which might be transferable to warm-blooded animals was the L-III stage of Anisakis sp. from the body cavity and the muscle of Muraenesox cinereus. The risk of human infections by parasites through consumption of raw marine fish in the central Philippines therefore is considered to be low.
\end{abstract}

\section{INTRODUCTION}

The aim of this study was to identify the risk of human infections by parasites through eating raw fish from central Philippine waters. Raw and semi-raw fish are common dishes in this area and fresh seafood is one of the major attractions for tourists.

Parasites transferred by sea fish to man are found rarely among the acanthocephalans (Bolbosoma sp.; Beaver et al. 1983, Tada et al. 1983), occasionally among the digeneans (several heterophyid species; Ito 1964, Taraschewski 1984) and cestodes (Diplogonoporus spp., Diphyllobothrium spp.; Baer et al. 1967, Kamo et al. 1971) and more frequently among the nematodes (Oshima 1972, Smith \& Wootten 1978).

Among the marine fish parasites, nematodes may cause the most severe problems for human health. Anisakidosis (or anisakiasis) is a painful inflammation of the human gastrointestinal tract caused by an invasion of the nematodes Anisakis spp. or Pseudoterranova decipiens. While gastric anisakidosis can be cured by removing the worm with endoscopic forceps, intestinal ansiakidosis may need surgical treatment. Several thousand cases have been reported from Japan, where sushi and ather raw dishes prepared from a variety of fish and squid are the source of infec- tion (Ishikura \& Namiki 1989, Ishikura \& Kikuchi 1990). However, anisakidosis has also been reported from a large number of other countries (Möller 1989), especially from The Netherlands and Germany, where slightly marinated herring (Clupea harengus) is the carrier of the nematodes (van Thiel 1976, Möller \& Schröder 1987).

Anisakis spp. uses euphausiids as intermediate hosts. Fish and squid serve as paratenic hosts for third stage larvae which mature in the stomachs of whales (Nagasawa 1990). In Pseudoterranova decipiens, the intermediate hosts are benthic crustaceans and the final hosts are seals (Bowen 1990). The fish-inhabiting nematode stages show a remarkable resistance to low temperature, but are destroyed readily by heating to $70^{\circ} \mathrm{C}$. The time to kill the nematodes by marinating depends on the degree of acidity, temperature and salt addition (Möller 1991).

'Kinilaw', a common dish in the Philippines, consists of freshly chopped flesh of various species of fish, squid or shellfish, marinated in a mixture of lemon juice, onions, garlic, ginger and tomatoes for usually 15 to $60 \mathrm{~min}$. It can be assumed that this treatment does not kill all, if any, parasites present in the flesh.

Studies of Philippine fish parasites in the past concentrated on helminths from fish in Palawan waters (Fischthal \& Kuntz 1964a, b, c, d), on parasites of cul- 


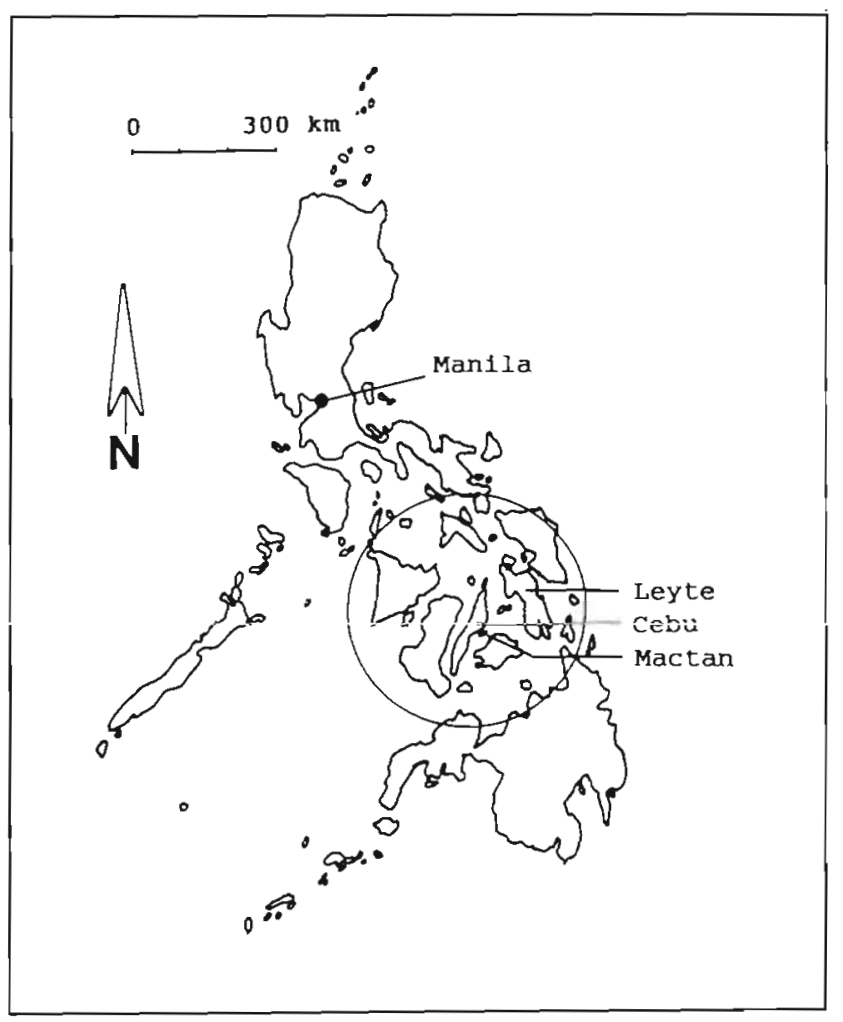

Fig. 1. Map of the Philippine Islands. The circle indicates the Visayan Sea

tured milkfish (Regidor \& Arthur 1986), on the occurrence of anisakid nematodes from Manila markets (Velasquez 1968, Jueco et al. 1971) and on the systematic group of the trematodes (Velasquez 1975). There is no information on marine fish parasites from the Visayan Sea in the central Philippines.

\section{MATERIALS AND METHODS}

In. April 1990, 488 fish belonging to 30 species were bought either from local markets or directly from fishermen on the islands of Cebu, Mactan and Leyte. In most cases the exact origin of the fish could not be determined, but there is no doubt that all of them came from the Visayan Sea (Fig. 1)

For fish identification, the keys by Rau \& Rau (1980) and Masuda (1984) were consulted. Examination was done immediately after purchase. The fish were measured and filleted and the skin removed. Thick fillets were sliced lengthwise, dark fillets were scraped with forceps. Thereafter, the fillets were pressed between 2 glass plates to make smaller parasites visible by placing a light source behind the plates. The body cavity and the surface of internal organs were searched for the presence of anisakid nematodes only. The search was done by naked eye. All parasites found were fixed in $70 \%$ alcohol. For the determination of the nematodes a compound microscope was used, and for the pleracercoids, a Joel JSM 6400 scanning electron microscope.

\section{RESULTS}

Four types of parasites were found in the fish flesh during this survey: unidentified, cyst-forming Microsporai plerocercoids of the cestode Otobothrium penetrans (Linton 1907) (Fig. 2); third stage larvae of the nematode Anisakis sp.; and adult females of the nematode Philometra sp. (Fig. 2).

A summary of the number of fish examined and the parasites found is given in Table 1. In 24 of 488 fish, parasites were found in the flesh. Eight of 30 fish species were infected. Microspora were observed in 6 fish belonging to 4 species. One to five cysts per fish were detected.

In 11 individuals of 4 fish species a total of 28 trypanorhynchid plerocercoids were found, with a maximum intensity of 8 in a single Tylosurus crocodilus. The habitus (Fig. 2) and the characteristic armature of the tentacles (Fig. 3) are equal to that of Otobothrium penetrans found in Tylosurus acus off the Bermudas (Linton 1907). This cestode species has never been described before from the west Pacific Ocean.

Larval Otobothrium penetrans occurred only in the flesh of belonids and hemirhamphids, probably due to similar diets. Species of both families feed on a variety of organisms taken from the surface layers of the sea. In the 4 species affected, the prevalence was in the order of $20 \%$. Nineteen of the 28 plerocercoids found were located in the flesh between the dorsal spines of the vertebral column, thus not occurring in the fillets (Fig. 4).

While a number of different nematode species were found between the viscera of the fish, only 2 species occurred in the flesh: 4 of 12 Tylosurus crocodilus harboured 1 aduit female Philometra sp. each, 2 of 13 Muraenesox cinereus harboured 1 Anisakis sp. larva, another harboured 3. Philometra sp., a very conspicuous red nematode, reached up to $18 \mathrm{~cm}$ in length when uncoiled from its cyst-like location. All of them contained viable larvae.

The occurrence of Anisakis sp. larvae was restricted to Muraenesox cinereus. Of 13 fish examined, 5 had larvae in the body cavity and 3 in the flesh. All Anisakis sp. found in the flesh were located in the belly flaps. The species determination is difficult due to overlapping morphometric characteristics of the 2 species A. simplex and A. typica (Oshima 1972, Shiraki 1974). 
None of the fish examined suffered from externally visible disease signs like tumors or ulcerations. The only type of skeletal deformity found was dilatation of the dorsal fin rays in Muraenesox cinereus as described earlier by Grabda (1982).

\section{DISCUSSION}

Results from this survey indicate that the risk of acquiring parasitoses from eating raw fish from central Philippine waters is low. Only $5 " \omega$ of the broad variety
Fig. 2. Macroscopic views (a) Otobothrium penetrans in fillet of Tylosurus acus. (b) Philometra sp. in fillet of Tylosurus crocodilus. Scale in $\mathrm{cm}$

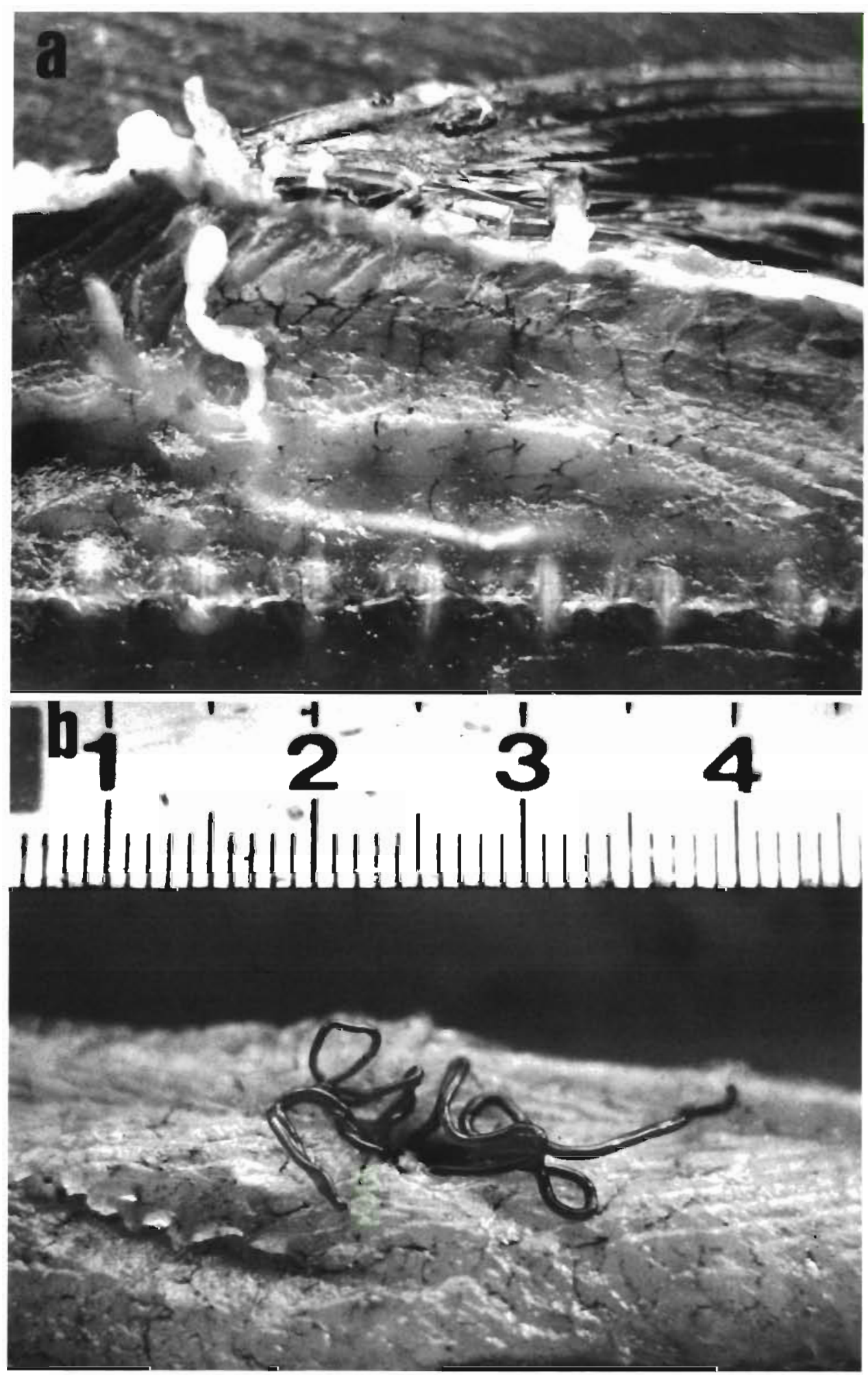


Table 1. Occurrence of parasites in the flesh of fish from the Visayan Sea. Mic: unidentified Microspora; Oto: Otobothrium penetrans; Phi: Philometra sp.; Ani: Anisakis sp.

\begin{tabular}{|c|c|c|c|c|c|}
\hline \multirow[t]{2}{*}{ Species } & \multirow[t]{2}{*}{ No. examined } & \multicolumn{4}{|c|}{ No. infected by: } \\
\hline & & Mic & Oto & Phi & Ani \\
\hline Dussumieria acuta & 16 & & & & \\
\hline Sardinella gibbosa & 28 & & & & \\
\hline Sardinella sirm & 29 & & & & \\
\hline Rastrelliger faughni & 31 & & & & \\
\hline Auxis rochei & 24 & & & & \\
\hline Selar crumenophthalamus & 15 & 2 & & & \\
\hline Stolephorus commersonii & 36 & & & & \\
\hline Stolephorus bataviensis & 75 & & & & \\
\hline Liza macrolepis & 8 & & & & \\
\hline Muraenesox cinereus & 13 & & & & 3 \\
\hline Nemipterus spp. & 20 & 2 & & & \\
\hline Siganus spp. & 17 & j. & & & \\
\hline Lelognathus splendens & 36 & & & & \\
\hline Sphyraena obtusata & 7 & & & & \\
\hline Caesio caerulaureus & 13 & & & & \\
\hline Caesio erythrogaster & 14 & & & & \\
\hline Hyporhamphus dussumieri & 10 & & 2 & & \\
\hline Hemirhamphus far & 20 & & & & \\
\hline Epinephelus megachir & 22 & & & & \\
\hline Platybelone sp. & 10 & & 2 & & \\
\hline Platybelone argalus & 3 & & & & \\
\hline Tylosurus acus & 22 & & 5 & & \\
\hline Tylosurus crocodilus & 12 & 1 & 2 & 4 & \\
\hline Parupeneus barberinus & 3 & & & & \\
\hline Parexocoetus sp. & 1 & & & & \\
\hline Crenimugil sp. & 3 & & & & \\
\hline Total: & 488 & 6 & 11 & 4 & 3 \\
\hline
\end{tabular}

of common local food fishes examined carried parasites in their flesh, and only $1.5 \%$ of them were infected when belonids and hemirhamphids are excluded.

Digenean metacercariae were not found, but they may have been present in the skin removed and the possibility cannot be excluded that very small stages in the flesh were overlooked during this survey. A transfer of Microspora from fish to man has never been reported and thus is unlikely. Trypanorhynchid cestodes

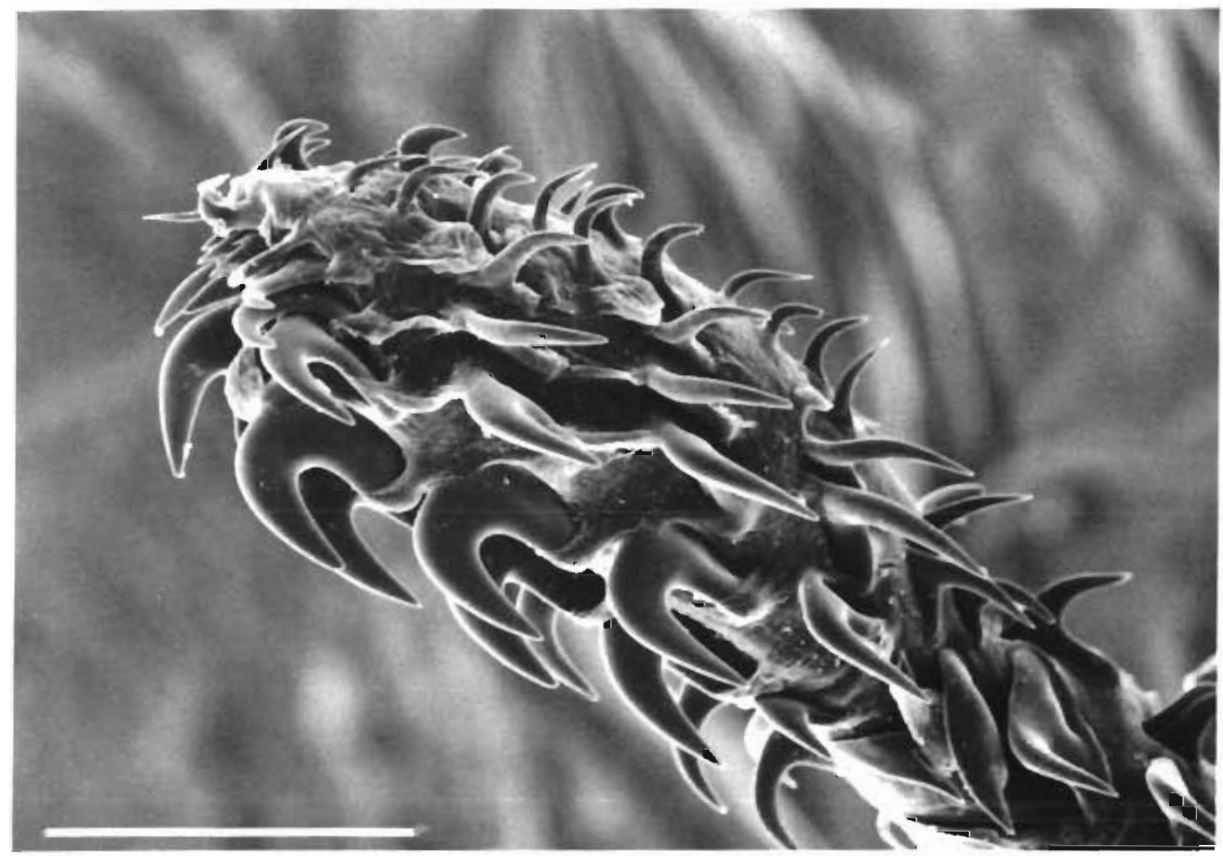

Fig. 3. Otobothrium penetrans from Tylosurus acus. SEM micrograph of the typical metabasal armature of tentacles of this plerocercoid. Scale bar $=100 \mu \mathrm{m}$ 


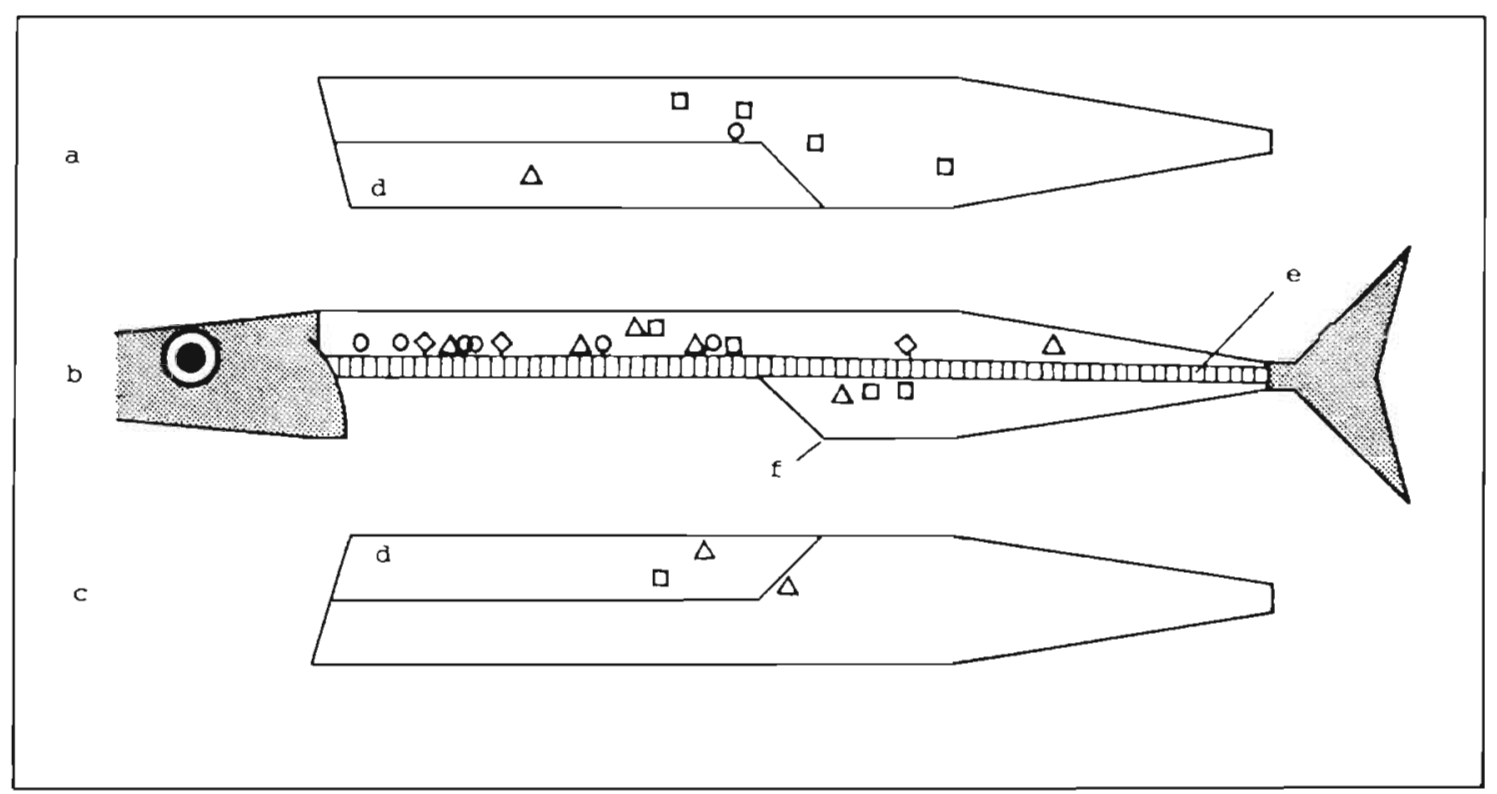

Fig. 4. Otobothrium penetrans. Position of 28 plerocercoids in the flesh of hemirhamphids and belonids from central Philippine waters. (a) Right fillet; (b) remnant of filleting; (c) left fillet; (d) belly flaps; (e) vertebral column; (f) anus. (O) Tylosurus crocodilus; $(\Delta)$ Tylosurus acus; $(\square)$ Platybelone sp.; $(\diamond)$ Hemirhamphus dussumieri

mature in elasmobranchs and occur only occasionally in warm-blooded animals or man (Kikuchi et al. 1981. Fripp \& Mason 1983). Nematodes of the genus Philometra are typical for tropical waters (Möller \& Anders 1986). They never have been found in warmblooded animals. The only parasite encountered which represents a potential risk to humans is Anisakis sp. During this survey its presence was restricted to Muraenesox cinereus, a species which is not used for preparing raw or semi-raw dishes. Nevertheless, conspicuous parasites like Otobothrium penetrans and Philometra sp. diminish the market value of the affected fish species.

Our findings differ from observations made by Velasquez (1968), who found Anisakis sp. larvae in the body cavity, gonads and occasionally in the muscle of 12 out of 47 fish species which were sold in Manila markets. Also Jueco et al. (1971) recorded high (41 to $100 \%$ prevalences of Anisakis sp. larvae in the carangid Decapterus macrosoma from Manila markets, exhibiting seasonal fluctuations with highest prevalences between September and February. Although our study was restricted to the month of April and it cannot be excluded that during other seasons more heavily parasitized fish migrate into the Visayan Sea, as shown earlier by Grabda (1974) for herring from the Polish coast, it is supposed that the infection level is lower than in the northern Philippine waters.

The low prevalence of Anisakis sp. larvae in fish from the Visayan Sea may be explained by the low population density of whales in the area, which have been sharply reduced by hunting. The lack of pinnipeds as final hosts explains the absence of the nematode Pseudoterranova decipiens in fish. However, the absence of nematode larvae of the genus Hysterothylacium, which are common in the flesh of a number of tropical fish species (Rohde 1984), also has to be mentioned and needs explanation.

For certain anisakid larvae a serial passage from the flesh of a food fish to the flesh of a predator fish has been documented (Burt et al. 1990). This might argue against the use of fresh unfrozen trash fish in aquaculture as it could lead to an undesirable accumulation of parasites in the flesh of cultured fish. It is important to note that this problem seems to be of only low significance for the central Philippines, an area which is predestined by its natural habitats for the cage culture of e.g. groupers and other highly priced fish species.

Acknowledgements. We thank the staff of the Marine Biology Section of the University of San Carlos, Cebu, for their assistance during the field research. This study was supported by 'Gesellschaft zur Förderung des Instituts für Meereskunde Kiel e.V.'.

\section{LITERATURE CITED}

Baer, J. G., Miranda, C. H., Fernandez, R. W., Meduia, T J (1967). Human diphyllobothriasis in Peru. Z. ParasitKde 28: $277-289$ 
Beaver, P. C., Otsuji, T., Otsuji, A., Yoshimura, H., Uchikawa, R., Sato, A. (1983). Acanthocephalan, probably Bolbosoma, from the peritoneal cavity of man in Japan. Am. J. trop. Med. Hyg. 32: 1016-1018

Bowen, W. D. (ed.) (1990). Population biology of sealworm ( $P$ seudoterranova decipiens) in relation to its intermediate and seal hosts. Can. Bull. Fish. Aquat. Sci. 222: 1-306

Burt, M. D., Campbell, J. D., Likely, C. G. (1990). Serial passage of larval Pseudoterranova decipiens (Nematoda: Ascaroideal in fish. Can. J Fish. Aquat. Sci. 47: 693-695

Fischthal, J. H., Kuntz, R. E. (1964a). Digenetic trematodes of fishes from Palawan Island, Philippines. I. Families Acanthocolpidae, Angiodictyidae, Cryptogonimidae, Fellodistomidae and Gyliauchenidae. J. Parasitol. 50: $248-252$

Fischthal, J. H., Kuntz, R. E. (1964b). Digenetic trematodes of fishes from Palawan Island, Philippines. Part II. Five Opecoelidae, including three new species. Proc. helminth. Soc. 'Mrash. 31. $40-4 \hat{G}$

Fischthal, J. H., Kuntz, R. E. (1964C). Digenetic trematodes of fishes from Palawan Island, Philippines. Part III. Families Hemiuridae and Lepocreadiidae. Proc. helminth. Soc. Wash. 31: 109-120

Fischthal, J. H., Kuntz, R. E. (1964d). Digenetic trematodes of fishes from Palawan Island, Philippines. IV. Some immature Didymozoidae, a bucephalid; a new hemiurid genus and subfamily. J. Parasitol. 50: 253-260

Fripp, P. J., Mason, P. R. (1983). Spurious human infection with a trypanorhynchid tapeworm. S. Afr. J. Sci. 79: 473

Grabda, E. (1982). Fungi-related outgrowths on pterygophores of single fins of Lepidopus caudatus (Euphrasen, 1788) (Pisces: Trichiuridae). Acta Ichthyol. Piscat. 12: 87-105

Grabda, J (1974). The dynamics of the nematode larva, Anisakis simplex (Rud.) invasion in the south-western Baltic herring (Clupea harengus L.). Acta Ichthyol. Piscat. 4: $3-21$

Ishikura, H., Kikuchi, K. (eds.) (1990). Intestinal anisakiasis: infected fish, sero-immunological diagnosis, and prevention. Springer, Tokyo

Ishikura, H., Namiki, M. (eds.) (1989). Gastric anisakiasis in Japan: epidemiology, diagnosis, treatment. Springer, Tokyo

Ito, J. (1964). Metagonimus and other human heterophyid trematodes. Progr. med. Parasitol. Japan 1: 315-393

Jueco, N. L., Bobis, T. A., Ramirez, L. M. (1971). Seasonal prevalence and density of Anisakis larvae in fish (galunggong) sold in public markets in Manila. J. Philipp. med. Ass. $47: 467-476$

Kamo, H., Hakushika, R., Yamane, Y (1971). Diplogonoporiasis and diplogonadic cestodes in Japan. Yonago Acta Med. 15: 234-246

Kikuchi, Y., Takenouchi, T., Kamiya, M., Ozaki, H. (1981).
Trypanorhynchid cestode larva found on the human palatine tonsil. Jap. J. Parasitol. 30:497-499 (in Japanese)

Linton, E. (1907). Notes on parasites of Bermuda fishes. Proc. U.S. natn. Mus. 33: 85-126

Masuda, $H$. (ed.) (1984). The fishes of the Japanese Archipelago, Vols. 1 \& 2. Tokaj Univ. Press, Tokyo

Möller, H. (1989). Biology of nematodes inhabiting marine fish flesh. Anim. Res. Dev. 30: 96-106

Möller, H. (1991). Prevention of human anisakiasis. VetMed Hefte 1/1991: 69-75

Möller, H., Anders, K. (1986). Diseases and parasites of marine fishes. Möller, Kiel

Möller, H., Schröder, S. (1987). Neue Aspekte der Anisakiasis in Deutschland. Arch. Lebensmittelhyg. 38: 123-128

Nagasawa, K. (1990). Life cycle of Anisakis simplex. In Ishikura, H., Kikuchi, K. (eds.) Intestinal anisakiasis: infected fish, sero-immunological diagnosis, and prevention. Springer, Tokyo, p. 31-40

Oshima, T (1972). Anisakis and anisakiasis in Japan and adjacent waters. Progr. med. Parasitol. Jap. 4: 301-393

Rau, N., Rau, A. (1980). Commercial marine fishes of the central Philippines. Deutsche Gesellschaft für Technische Zusammenarbeit, Eschborn

Regidor, S. E., Arthur, J. R. (1986). Parasites of juvenile milkfish, Chanos chanos. In: Maclean, J. L., Dizon, L. B., Hosillos, L. V. (eds.) The first Asian fisheries forum, Vol. I. Asian Fisheries Society, Manila, p. 261-264

Rohde, K. (1984). Pisces. Diseases caused by metazoans: Helminths. In: Kinne, O. (ed.) Diseases of marine animals, Vol. 4, Part 1. Biologische Anstalt Helgoland, Hamburg, p. $193-320$

Shiraki, T (1974). Larval nematodes of family Anisakidae (Nematoda) in the northern Sea of Japan as a causative agent of eosinophilic phlegmone or granuloma in the human gastro-intestinal tract. Acta Med. Biol. 22: $57-98$

Smith, J. W. Wootten, R. (1978). Anisakis and anisakiasis. Adv. Parasitol. 16: 93-163

Tada, I., Otsuji, Y., Kamiya, H., Mimori, T., Sakaguchi, Y., Makisumi, S. (1983). The first case of a human infected with an acanthocephalan parasite, Bolbosoma sp. J. Parasitol. 69: 205-208

Taraschewski, H. (1984). Heterophyiasis, an intestinal fluke infection of man and vertebrates transmitted by euryhaline gastropods and fish. Helgoländer Meeresunters. 37: $463-478$

van Thiel, P. H. (1976). The present state of anisakiasis and its causative worms. Trop. geogr. Med. 28: 75-85

Velasquez, C. C. (1968). Résumé of findings on Anisakis larvae. Univ. Philipp. zool. Soc. Publ. 4: 17

Velasquez, C. C. (1975). Digenetic trematodes of Philippine fishes. Univ. of the Philippines Press, Quezon City 